\title{
Transient suppression of nuclear Cdc2 activity in response to ionizing radiation
}

\author{
MIN-JUNG KIM*, JEONG-YIM LEE* and SU-JAE LEE \\ Laboratory of Molecular Biochemistry, Department of Chemistry, Hanyang University, Seoul 133-791, Korea
}

Received October 9, 2007; Accepted December 10, 2007

\begin{abstract}
Suppression of Cdc2 activity is essential for DNA damage-induced $\mathrm{G} 2$ arrest. In the present study, we elucidated regulatory mechanism of $\mathrm{Cdc} 2$ activity during radiation-induced transient $\mathrm{G} 2$ arrest. Exposure of the cells to $\gamma$-radiation (4 Gy) led to a transient increase of cells in G2 at $12 \mathrm{~h}$ rather than $\mathrm{M}$ phase and then the cells resumed cell cycle progression from the G2 arrest. However, the levels of cyclin B1 and Cdc2 activity were increased in the whole cell extracts at $12 \mathrm{~h}$. Despite cyclin B1 induction and increased level of Cdc2 activity after irradiation the activities in the nuclear fractions were transiently decreased at $12 \mathrm{~h}$ and returned to control levels by $24-48 \mathrm{~h}$, demonstrating transient inhibition of nuclear translocation of cyclin B1 in response to radiation. Moreover, inhibitory phosphorylation of the $\mathrm{Cdc} 2$ on Tyr15 and the Cdc25C on Ser216 were increased concomitant with transient G2 arrest. The level of phosphorylated Wee 1 and its activity were also markedly increased at $12 \mathrm{~h}$ after irradiation. In addition, radiation caused nuclear accumulation of $\mathrm{p} 21^{\mathrm{CIP} 1 / \mathrm{WAF} 1}$ at $12 \mathrm{~h}$, resulting in increased-binding of $\mathrm{p} 21^{\mathrm{CIP} 1 / \mathrm{WAF} 1}$ to Cdc2. Nuclear $\mathrm{p} 21^{\mathrm{CIP} 1 / \mathrm{WAF} 1}$ protein level and its binding to $\mathrm{Cdc} 2$ gradually returned to control level when the cells resumed cell cycle progression. However, total protein level of $\mathrm{p} 21^{\mathrm{CIP} 1 / \mathrm{WAF} 1}$ continued to increase until $48 \mathrm{~h}$ after irradiation. Collectively, these results indicate that the suppression of nuclear import of cyclin B1, the induction of Wee1 kinase activity, and the transient nuclear accumulation of $\mathrm{p} 21^{\mathrm{CIP} 1 / \mathrm{WAF} 1}$ may play important roles in the transient cell cycle delay in response to ionizing radiation.
\end{abstract}

Correspondence to: Dr Su-Jae Lee, Laboratory of Molecular Biochemistry, Department of Chemistry, Hanyang University, 17 Haengdang-Dong, Seongdong-Ku, Seoul 133-791, Korea E-mail: sj0420@hanyang.ac.kr

${ }^{*}$ Contributed equally

Abbreviations: Cdk, cyclin-dependent kinase; CKI, cyclindependent kinase inhibitor; GST, glutathione S-transferase

Key words: Cdc2, ionizing radiation, cyclin B1

\section{Introduction}

Ionizing radiation induces a variety of responses in eukaryotic cells including cell division delay and DNA repair $(1,2)$. In mammalian cells, this division delay may have several components including G1 arrest, S phase delay, and G2 arrest (3). Activation of these DNA damage checkpoints has been proposed to allow DNA repair to occur before entering into $\mathrm{S}$ phase or mitosis (4-6), and the failure in DNA damage repair at these checkpoints may cause irreversible alterations to the genome, which can have profound effects on cellular viability and coordinated cell proliferation and development (7-9).

The basic components of cell cycle progression are protein complexes [cyclin-cyclin dependent kinases (Cdks)] that are activated in an ordered fashion and trigger the initiation of specific events such as DNA replication, nuclear envelope breakdown, spindle formation, and chromosome segregation (10). The transition from the G2 phase of the cell cycle into mitosis is regulated by timely and coordinated activation of the cyclin-dependent protein kinase $\mathrm{Cdc} 2$, which functions as a heterodimeric complex consisting of $\mathrm{Cdc} 2$ and cyclin B1 proteins (11). The DNA damage-induced cell cycle delay results from a down-regulation of the cyclin B1/Cdc 2 complex formation and shift of the complex from cytoplasm to nucleus through perinuclear pores. It has been reported that the translocation of cyclin B1 to the nucleus is essential for the G2/M transition (12).

The association of $\mathrm{Cdc} 2$ with cyclin B1 is necessary, but not sufficient for generation of kinase activity. The activity of $\mathrm{Cdc} 2$ is tightly regulated by a variety of mechanisms, such as periodic cyclin accumulation and degradation, nuclear localization, phosphorylation, and association with different Cdk inhibitors (CKI) $(11,13,14)$. The kinase activity of Cdc2 during the cell cycle is controlled by both its association with cyclin B 1 and phosphorylation/dephosphorylation of the inhibitory phosphorylation sites, Thr-14 and Tyr-15 (15-17). In mammalian cells, phosphorylation of $\mathrm{Cdc} 2$ catalyzed by Wee1/Myt1 (also related) tyrosine kinases at Tyr15 and Thr14 is important in negative regulation of kinase activity, whereas dephosphorylation at the same sites is facilitated by $\mathrm{Cdc} 25$ (and related) tyrosine phosphatases. During the checkpoint delay, Wee1 is transiently hyperphosphorylated and stabilized, and both $\operatorname{Cdc} 25$ and Wee1 are thought to be important in coupling mitosis and cell division to earlier events in the cell cycle $(18,19)$. 
Previous data suggest that Cdk inhibitor $\mathrm{p} 21^{\mathrm{CIP} 1 / \mathrm{WAF} 1}$ may also be important for $\mathrm{G} 2 / \mathrm{M}$ arrest in mammalian cells $(7,16,20,21)$. The $\mathrm{p} 21$ protein was identified by its ability to bind and inhibit Cdk2-cyclin E and/or Cdc2-cyclin B1 complexes. The $\mathrm{p} 21^{\mathrm{CIP} 1 / \mathrm{WAF} 1}$-mediated inhibition of cyclin-Cdk complexes might contribute to radiation-induced G2 arrest, even though $\mathrm{p} 21^{\mathrm{CIP} 1 / \mathrm{WAF} 1}$ might not be absolutely essential for the immediate G2 checkpoint responses (12). However, transient nuclear accumulation of $\mathrm{p} 21^{\mathrm{CIP} 1 / \mathrm{WAF} 1}$ during cell cycle regulation after ionizing irradiation has not been explored.

In the present study, we explored molecular mechanism of the regulation of nuclear $\mathrm{Cdc} 2$ activity during radiationinduced G2 arrest in exponentially growing L929 cells. We show that inhibition of nuclear import of cyclin B 1 and transient nuclear localization of $21^{\mathrm{CIP} 1 / \mathrm{WAF} 1}$ as well as inhibition of $\mathrm{Cdc} 25 \mathrm{C}$ and induction of Wee1 activity are associated with the regulation of nuclear Cdc2 activity during cell cycle arrest by ionizing radiation.

\section{Materials and methods}

Cell culture. Murine L929 fibroblasts were maintained in Dulbecco's minimal essential medium (DMEM), supplemented with $10 \%$ fetal bovine serum and $1 \%$ antibiotic/antimycotic solution (Gibco BRL), at $37^{\circ} \mathrm{C}$ under humidified $5 \% \mathrm{CO}_{2}$ $95 \%$ air.

Irradiation and cell cycle analysis. L929 fibroblasts were irradiated with 4 Gy by using a $\gamma$-cell irradiator with ${ }^{137} \mathrm{Cs}$ source (Atomic Energy of Canada, Ltd., Canada). After harvesting, unirradiated and irradiated cells were fixed in $70 \%$ ethanol and stored at $-20^{\circ} \mathrm{C}$. Cells were then washed twice with ice-cold PBS and incubated with RNase and propidium iodide, DNA intercalating dye, and cell cycle phase analysis was performed by flow cytometry using a Becton Dickinson Facsplus flow cytometer and Becton Dickinson Cell fit software.

Cell growth assay. Cell growth was assessed over a period of 2 days. Cells $\left(4 \times 10^{4}\right)$ were plated in $30-\mathrm{mm}$ dishes and incubated in $10 \%$ FBS in DMEM until $60 \%$ confluent. Subsequently, the cells were irradiated with 4 Gy and incubated for $12,24,36$, and $48 \mathrm{~h}$. The number of cells was enumerated using a hematocytometer. Each point on the growth curve represents the mean of three independent experiments, each experiment was counted 4 times.

Measurement of mitotic index. Cells $\left(1 \times 10^{5}\right)$ were grown on the cover slip and treated with $4 \mathrm{~Gy}$ radiation in the presence or absence of a mitotic inhibitor, nocodazole $(0.4 \mu \mathrm{g} / \mathrm{ml})$, to trap those cells entering mitosis. After 12, 24, 36, and $48 \mathrm{~h}$, the cells were fixed with $3 \%$ formaldehyde, incubated with $50 \mathrm{ng} / \mathrm{ml}$ Hoechst 33258 for $5 \mathrm{~min}$, and mounted with glycerol. Mitotic cells were enumerated under a fluorescence microscope (Nikon, Japan). The mitotic index was determined by counting at least 300 cells for each sample. The data represent average of three experiments with standard deviation, each experiments being counted 3 times.

Cell fractionation. Cells $\left(1 \times 10^{6}\right)$ grown on $10-\mathrm{cm}$ tissue culture dishes were washed once with ice-cold PBS and harvested with a scraper. Cell pellets were resuspended in hypotonic buffer (10 mM HEPES, $10 \mathrm{mM} \mathrm{KCl,} 0.1 \mathrm{mM}$ EDTA, $0.1 \mathrm{mM}$ EGTA, $0.5 \%$ Nonidet P-40) and incubated at $4^{\circ} \mathrm{C}$ for $15 \mathrm{~min}$. Samples were agitated every $5 \mathrm{~min}$ and then centrifuged at $12,000 \mathrm{x} g$ for $30 \mathrm{sec}$ to collect the cytoplasmic fraction. The pellets were resuspended and incubated in nuclear extraction buffer (20 mM HEPES, 20\% glycerol, $0.42 \mathrm{M} \mathrm{NaCl}, 1 \mathrm{mM}$ EDTA, $1 \mathrm{mM}$ EGTA) for $30 \mathrm{~min}$, and centrifuged at 12,000 x g for $20 \mathrm{~min}$ to collect the nuclear fraction. The protein concentration of supernatants was determined by Bio-Rad protein assay system.

Immunoprecipitation. Cells were lysed with TNN buffer [40 mM Tris-Cl (pH 8.0), $120 \mathrm{mM} \mathrm{NaCl,} \mathrm{0.1 \%} \mathrm{Nonidet} \mathrm{P-40]}$ containing $2 \mu \mathrm{g} / \mathrm{ml}$ leupeptin, $100 \mu \mathrm{M}$ AEBSF [4-(2aminoethyl)-benzenesulfonyl fluoride hydrochloride] and $100 \mu \mathrm{M}$ sodium orthovanadate. Cell debris was removed by centrifugation at $12,000 \mathrm{x}$ g for $15 \mathrm{~min}$. For co-immunoprecipitation analysis, the supernatants were then incubated with rabbit polyclonal $\mathrm{Cdc} 2$ antibody for $90 \mathrm{~min}$ at $4^{\circ} \mathrm{C}$ and the immune complexes were collected on protein A-sepharose (Sigma) for $90 \mathrm{~min}$ at $4^{\circ} \mathrm{C}$, washed 5 times with TNN buffer and then analyzed by SDS-polyacrylamide gel electrophoresis. The p $21^{\mathrm{CIP} 1 / \mathrm{WAF} 1}$ co-immunoprecipitated with $\mathrm{Cdc} 2$ was detected by Western blot analysis.

Immunoblot analysis. Cell lysates were prepared by extracting proteins with lysis buffer [40 mM Tris- $\mathrm{Cl}$ (pH 8.0), $120 \mathrm{mM}$ $\mathrm{NaCl}, 0.1 \%$ Nonidet $\mathrm{P}-40]$ supplemented with protease inhibitors. Proteins were separated by SDS-polyacrylamide gel electrophoresis and transferred to nitrocellulose membrane. The membrane was blocked with 5\% nonfat dry milk in Tris buffered saline and then incubated with primary antibodies for $1 \mathrm{~h}$ at room temperature. The following antibodies were purchased from Santa Cruz Biotechnology (Santa Cruz, CA) and New England Biolabs (NEB): Mouse monoclonal anticyclin B1 (sc-245), rabbit polyclonal anti-Cdc25B (sc-326) and anti-Cdc25C (sc-327), rabbit polyclonal anti-Wee1 (sc-325), rabbit polyclonal anti-p21 (sc-397), mouse monoclonal antiCdc2 (sc-254), and rabbit monoclonal anti-phosphotyrosine $15 \mathrm{Cdc} 2$ antibody (NEB). Blots were developed by peroxidaseconjugated secondary antibody and proteins were visualized by enhanced chemiluminescence (ECL) procedures (NEN) according to the manufacturer's recommendations.

Construction and preparation of GST-Cdc2. The open reading frame of murine Cdc2 gene in pBluescript SK was amplified by PCR using the following two primers: forward primer (5'-AAAAGGATCCCTATGGAAFACTATATCAAAATAG AGAA-3', BamHI site) and reverse primer (5'-AAAACTCGA GCATCTTCTTAATCTGATTGTCCAAG-3', XhoI site). The PCR product was digested with BamHI and XhoI, and ligated with pGEX-5X-2 digested with the same restriction enzymes. The resulting plasmid was analyzed by DNA sequencing and restriction enzyme digestion. The plasmid was named pGEXCdc2. GST-Cdc2 was isolated from E. coli BL21/pGEX-Cdc2 by RediPack GST purification module (Amersham Pharmacia).

Immune complex kinase assay. Immune complex kinase assays were performed as described (23). Briefly, cells were lysed 
A

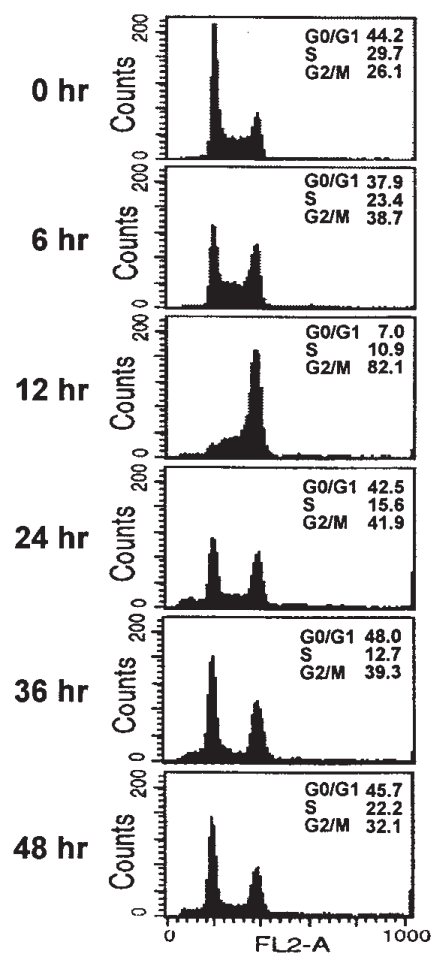

Whole cell extract

$\begin{array}{llllllll}\text { Time after IR } & 0 & 6 & 12 & 24 & 36 & 48 & (\mathrm{hr})\end{array}$

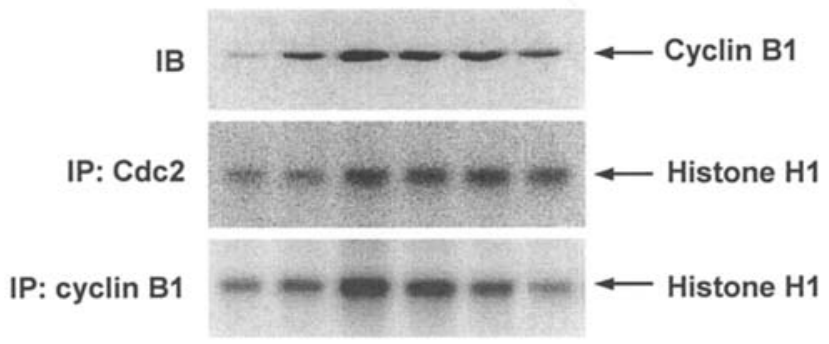

Figure 2. Changes in the levels of cyclin B1 and Cdc2 activity after ionizing irradiation in whole cell extracts. L929 cells were treated with 4 Gy $\gamma$-radiation. At times indicated, the cells were harvested and whole cell extracts were analyzed by immunoblot (IB) or immunoprecipitation (IP) with anti-Cdc2 or anti-cyclin B1 antibodies. Cdc2 activity and cyclin B1associated $\mathrm{Cdc} 2$ activity were measured using histone $\mathrm{H} 1$ as a substrate. The data represent typical results from an experiment repeated 3 times with similar results.

with TNN buffer, and clarified extracts were incubated with cyclin $\mathrm{B} 1$ or Weel antibodies for $90 \mathrm{~min}$ at $4^{\circ} \mathrm{C}$. Immunocomplexes were precipitated with protein A-sepharose, and washed 3 times with TNN buffer and twice with kinase buffer [25 mM Tris-Cl ( $\mathrm{pH} \mathrm{7.4),} 10 \mathrm{mM} \mathrm{MgCl}_{2}$ ]. Pellets were incubated in kinase buffer containing $2 \mu \mathrm{Ci}\left[\gamma_{-}{ }^{32} \mathrm{P}\right] \mathrm{ATP}$ and $2 \mu \mathrm{g}$ histone $\mathrm{H} 1$ or GST-Cdc2 as substrates for $30 \mathrm{~min}$ at $37^{\circ} \mathrm{C}$, and the reactions were terminated by adding SDS sample buffer. The mixtures were then boiled for $3 \mathrm{~min}$ and separated on $12 \%$ SDS-polyacrylamide gel, and bands were detected by autoradiography.
B

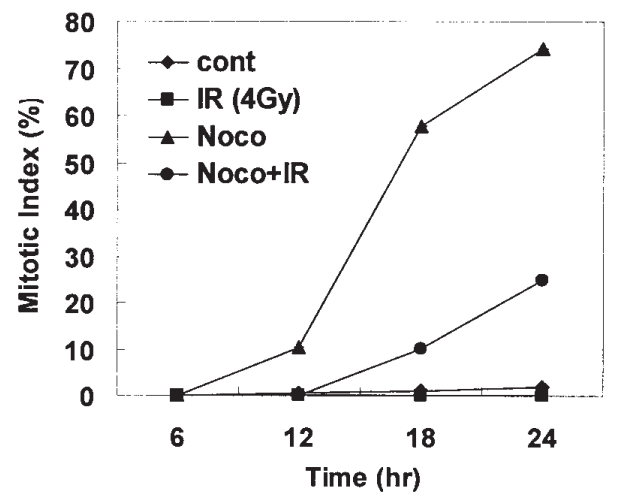

Figure 1. Ionizing radiation-induced transient G2 arrest in L929 cells. (A) Exponentially growing cells were irradiated with 4 Gy. After 6, 12, 24, 36, and $48 \mathrm{~h}$, the cells were harvested and subjected to flow cytometric analysis to determine cell cycle distribution. (B) Cells were treated with $4 \mathrm{~Gy}$ radiation in the presence or absence of a mitotic inhibitor, nocodazole $(0.4 \mu \mathrm{g} / \mathrm{ml})$, to trap the cells entering mitosis. After $12,24,36$, and $48 \mathrm{~h}$, the cells were stained with Hoechst 33258 for $5 \mathrm{~min}$ and mitotic cells were enumerated using a fluorescence microscope. The percentage of cells in mitotic phase (mitotic index) was determined by counting at least 300 cells for each sample. The data represent means of three independent experiments with standard deviation, and each sample was counted 4 times.

Immunofluorescence analysis. Exponentially growing L929 cells were irradiated with $4 \mathrm{~Gy}$, followed by incubation for $12 \mathrm{~h}$. The cells were fixed with $3 \%$ formaldehyde in PBS for 20 min and incubated for 5 min with PBS containing $0.5 \%$ Triton X-100. Subsequently, the cells were incubated with anti-cyclin B1 and p21 antibody (diluted at 1:1,000) for $1 \mathrm{~h}$ at room temperature. After washing with PBS, FITC-conjugated secondary antibodies were added and further incubated for $1 \mathrm{~h}$. The cells were washed with PBS, mounted in glycerol, and examined with a fluorescence microscope (Nikon).

\section{Results}

Ionizing radiation induces transient G2 arrest in L929 cells. Cells irradiated with 4 Gy exhibited a significant growth delay as compared to that of unirradiated cells (data not shown). To determine whether the radiation-induced growth delay was due to an arrest in any specific cell cycle phase, we performed flow cytometric analysis. As shown in Fig. 1A, 4 Gy irradiation led to a marked increase of the cells in $\mathrm{G} 2 / \mathrm{M}$ at $12 \mathrm{~h}(>80 \%)$. The progression of cell cycle through $\mathrm{G} 2 / \mathrm{M}$ phase was apparent at $24 \mathrm{~h}$ and the cell cycle profile returned to normal by $48 \mathrm{~h}$ after irradiation. However, the results of flow cytometric analysis did not clearly discern whether ionizing radiation caused the increase of cells in $\mathrm{G} 2$ phase or in $\mathrm{M}$ phase. To address this problem, we performed Hoechst 33258 staining of the cells irradiated with 4 Gy radiation in the presence or absence of a mitotic inhibitor, nocodazole $(0.4 \mu \mathrm{g} / \mathrm{ml})$, in order to trap the cells entering mitosis, and mitotic cell population was measured: if the cells were already arrested at G2 phase after radiation, the drug should have little or no effect. On the other hand, if the cells 


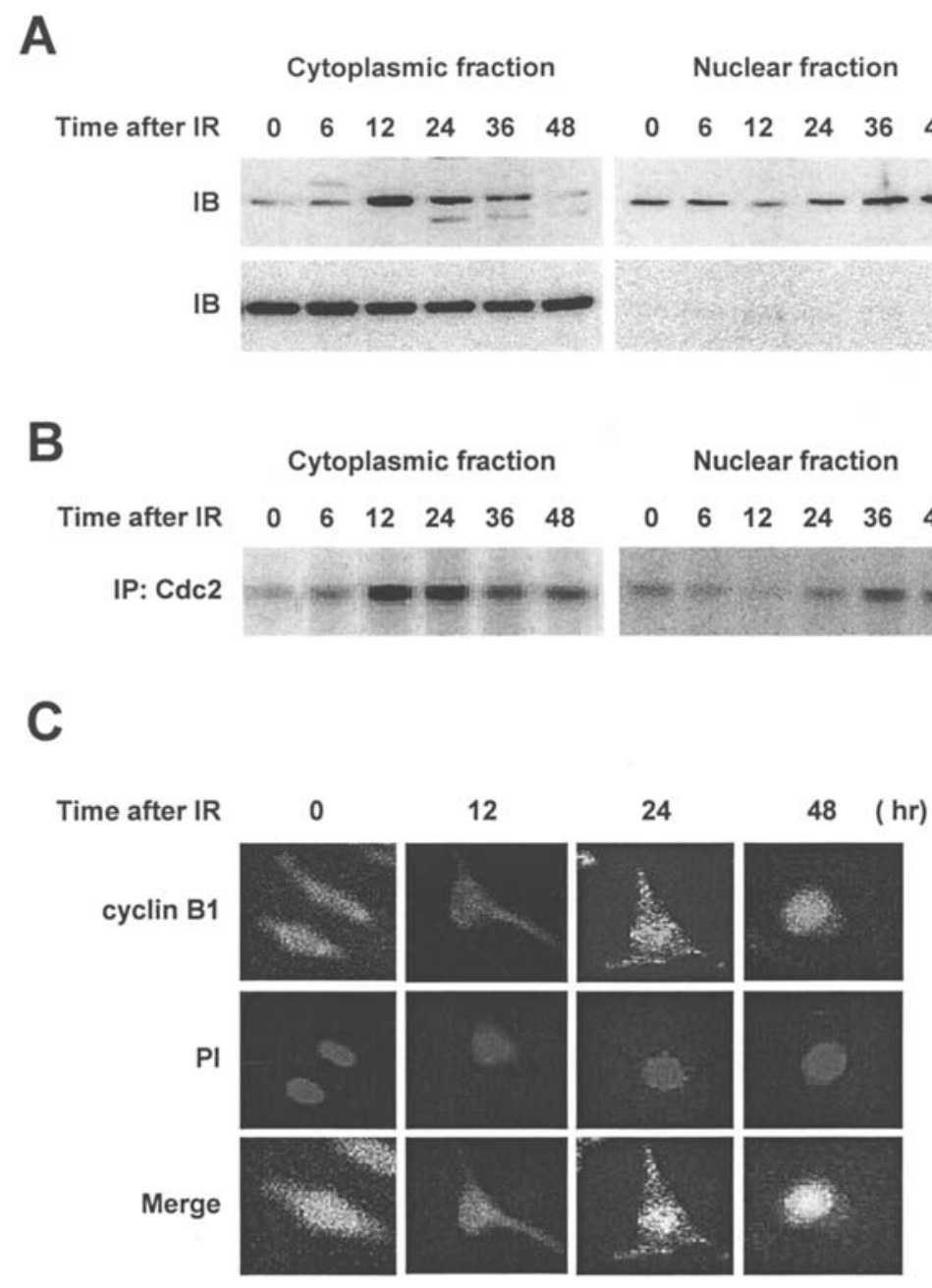

Figure 3. Delayed nuclear import of cyclin B1 after ionizing irradiation. Cells were treated with 4 Gy ionizing irradiation. (A) At times indicated, cytoplasmic and nuclear subcellular fractions were subjected to immunoblot analysis with anti-cyclin B1 antibody. Samples were probed for tubulin as a cytoplasmic marker. The data represent results from a typical experiment carried out $>3$ times with similar results. (B) At times indicated, cytoplasmic and nuclear subcellular fractions were immunoprecipitated (IP) with anti-Cdc2 antibody, and kinase activity was measured using histone H1 as a substrate. The data represent results from a typical experiment performed 3 times with similar results. (C) After 12 and $48 \mathrm{~h}$, cells were incubated with propidium iodide (PI) and stained with anti-cyclin B1 antibody. The slides were analyzed by a confocal laser scanning microscope. Nuclear localization of cyclin B1 was defined by overlap of FITC and PI.

progressed through G2 phase and were arrested at mitosis, the nocodazole treatment would further increase the mitotic index. As shown in Fig. 1B, incubation of growing cells with nocodazole alone caused a marked increase in the mitotic index. However, the mitotic index of the cells irradiated with $4 \mathrm{~Gy}$ in the presence of nocodazole did not increase until $12 \mathrm{~h}$ of post-radiation even though the cells at $\mathrm{G} 2 / \mathrm{M}$ phase reached $82 \%$ (Fig. 1A) at this time point suggesting that treatment of growing L929 cells with ionizing radiation primarily induced G2 arrest, but not mitotic arrest.

Changes in the levels of cyclin B1 and Cdc2 activity after ionizing irradiation in whole cell extracts. Transition from $\mathrm{G} 2$ to $\mathrm{M}$ phase requires Cdc2 activity regulated by levels of cyclin $\mathrm{B} 1$ proteins as well as by phosphorylation status of Cdc2 at Tyr15. Therefore, we examined changes in the levels of cyclin B1 protein after 4 Gy irradiation. As shown in Fig. 2, immunoblot analysis of whole cell extracts harvested 6-48 h after irradiation revealed that the level of cyclin B1 protein was transiently increased until $12 \mathrm{~h}$ and returned to control levels by 48 h. Moreover, a direct and cyclin B1-associated Cdc2 activity also increase at 6-12 $\mathrm{h}$ after radiation treatment and gradually returned to control levels at $24-48 \mathrm{~h}$ (Fig. 2). The two phenomena, which are the increase of Cdc2 activity and transient G2 arrest, clearly contradict each other, since Cdc2 activity is required for cells to progress through $\mathrm{G} 2 / \mathrm{M}$ phase.

Inhibition of nuclear import of cyclin B1 protein and $C d c 2$ activity after irradiation. To elucidate the reason why the levels of cyclin B1 proteins and Cdc 2 activity were upregulated in the presence of increased inactivating phosphorylation of $\mathrm{Cdc} 2$ and radiation-induced G2 arrest, subcellular distribution of cyclin B1 proteins and $\mathrm{Cdc} 2$ activity following irradiation were examined. Thus, cells were irradiated with $4 \mathrm{~Gy}$, fractionated into cytoplasmic and nuclear fractions, and protein levels of cyclin B1 and Cdc2 activity were examined. As shown in Fig. 3A, cyclin B1 levels in the cytoplasmic fraction increased in a transient manner at 6-12 h, similar to the results with whole cell extract. Cdc2 activity was 


\section{A}

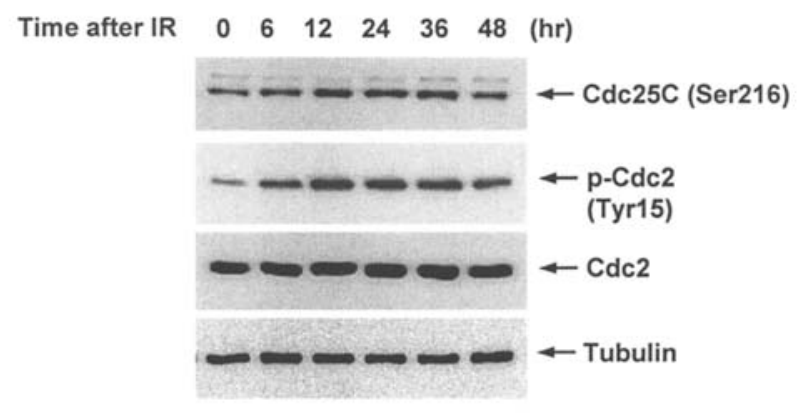

B

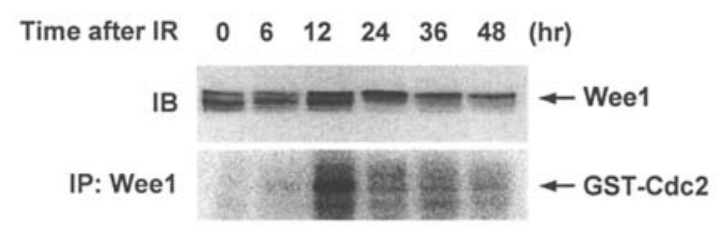

Figure 4. Changes in the phosphorylation status of $\mathrm{Cdc} 2$ and the kinase activity of Wee1 following ionizing radiation. L929 cells were treated with 4 Gy $\gamma$-radiation. (A) At times indicated, the cells were harvested and whole cell extracts were subjected to immunoblot analysis with anti-Cdc2, antiphospho-Cdc2, anti-Cdc25C or anti-tubulin antibodies. The data represent typical results from an experiment repeated 3 times with similar results. (B) At times indicated, the cells were harvested and whole cell extracts were prepared. The extracts were analyzed by immunoblot (IB) or immunoprecipitation (IP) with anti-Wee1 antibody to measure kinase activity using GST-Cdc2 as a substrate. The data represent typical results from an experiment repeated 3 times with similar results. also transiently induced until $12 \mathrm{~h}$ and returned to the control level by $48 \mathrm{~h}$ (Fig. 3B). However, cyclin B1 protein level in the nuclear fraction decreased until $12 \mathrm{~h}$ (Fig. 3A). The Cdc2 activity was also gradually decreased until $12 \mathrm{~h}$ after irradiation (Fig. 3B), which corresponded well with Cdc2 phosphorylation and transient G2 arrest. When the cells later resumed cell cycle progression from the G2 arrest, cyclin B1 protein level and nuclear cdc2 activity returned to normal. Indirect immunofluorescence staining clearly indicated that cyclin B 1 proteins were not translocated to the nucleus. Instead, they accumulated in the cytoplasm at $12 \mathrm{~h}$ (Fig. 3C). These data suggest that delayed import of cyclin B1 into the nucleus may play a role in the inhibition of nuclear $\mathrm{Cdc} 2$ kinase activity after ionizing radiation.

Changes in phosphorylation status of Cdc2, Cdc25C and Wee1 activity following ionizing radiation. Since $\mathrm{Cdc} 2$ activation is essential for the G2/M transition and Cdc2 activity is regulated by phosphorylation status of $\mathrm{Cdc} 2$, we examined changes of phosphorylation status of $\mathrm{Cdc} 2$ and $\mathrm{Cdc} 25 \mathrm{C}$ (Cdc2 activating phosphatase), also changes of levels and activity of Wee1 protein ( $\mathrm{Cdc} 2$ inhibitory kinase) after ionizing irradiation. As shown in Fig. 4A, 4 Gy radiation-induced a marked accumulation of Cdc2 phosphorylated at Tyr15 and Cdc25C phosphorylated at Ser216 at $12 \mathrm{~h}$ of post-irradiation. In addition, Cdc2 inhibitory kinase Wee1 protein level and its activity were also markedly increased at $12 \mathrm{~h}$ after radiation (Fig. 4B), concomitantly with increase in Tyr15-phosphorylated $\mathrm{Cdc} 2$. When the cells were released from G2

A

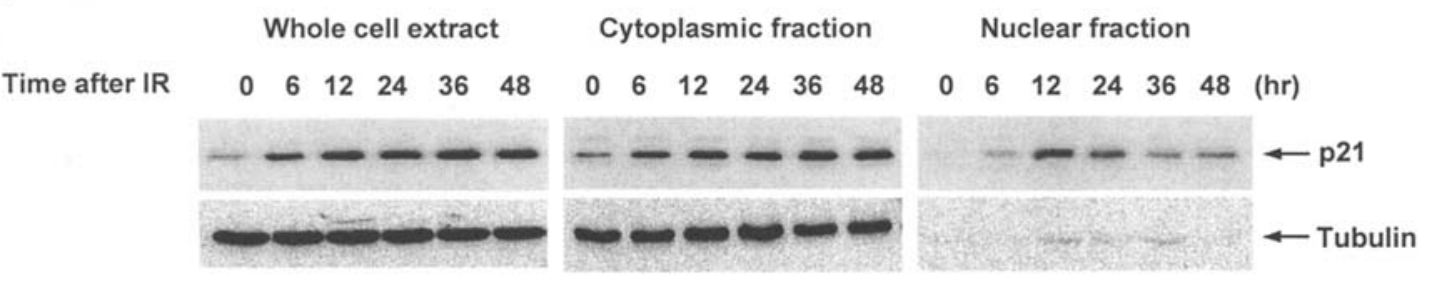

B

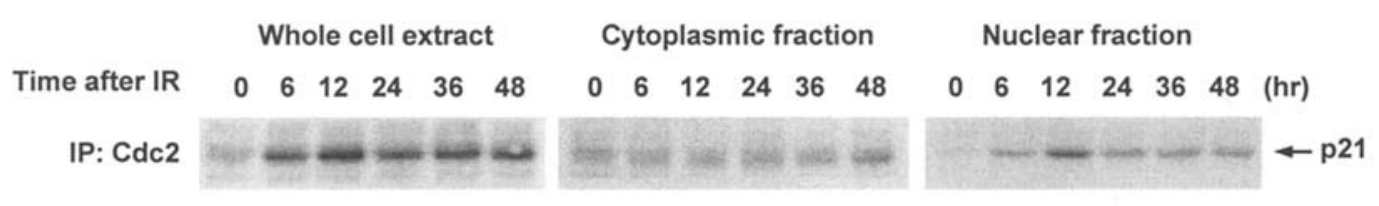

\section{C}

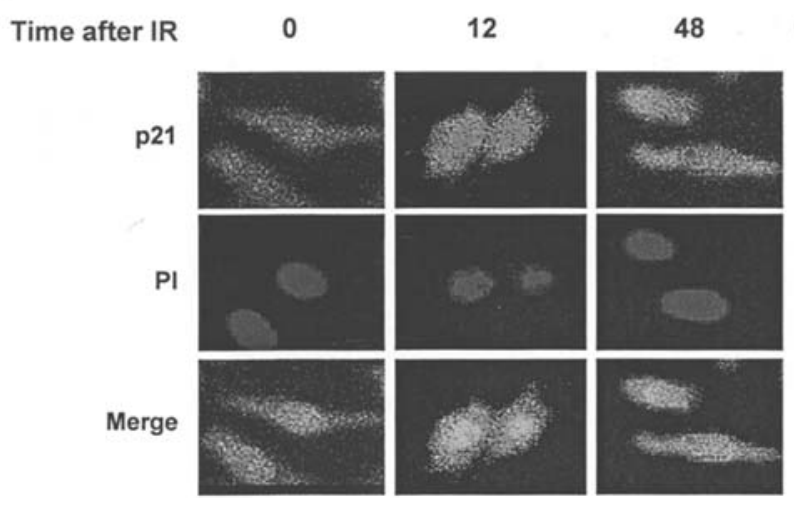

(hr)

Figure 5. Transient nuclear accumulation of $\mathrm{p} 21^{\mathrm{CIP} / \mathrm{WAF} 1}$ and its interaction with $\mathrm{Cdc} 2$ after ionizing irradiation. (A) Cytoplasmic and nuclear fractions were obtained at the indicated times after 4 Gy ionizing irradiation. Fractions were subjected to immunoblot (IB) analysis with anti-p21 $1^{\mathrm{WAF} / \mathrm{CIP1}}$ antibody. Samples were probed for tubulin as cytoplasmic marker. (B) Fractions were immunoprecipitated (IP) with anti-Cdc2 antibody and subjected to immmunoblot analysis with anti-p21 $1^{\mathrm{WAF} / \mathrm{CIP} 1}$ antibody. The data represent results from a typical experiment conducted 3 times with similar results. (C) Cells were treated with 4 Gy ionizing irradiation. After 12 and $48 \mathrm{~h}$, cells were incubated with propidium iodide (PI) and stained with anti$\mathrm{p} 21^{\mathrm{WAF} / \mathrm{CIP1}}$ antibody. The slides were analyzed by a confocal laser scanning microscope. Nuclear localization of $\mathrm{p} 21^{\mathrm{WAF} / \mathrm{CIP} 1}$ was defined by overlap of FITC and PI. 
arrest, the levels of phosphorylated $\mathrm{Cdc} 2$ and $\mathrm{Cdc} 25 \mathrm{C}$, and Wee1 activity were decreased. These results suggest that transient inactivation of $\mathrm{Cdc} 25 \mathrm{C}$ and activation of Wee 1 transiently down-regulate $\mathrm{Cdc} 2$ activity during the radiationinduced G2 arrest.

Transient nuclear accumulation of $p 21^{C I P I / W A F 1}$ and its interaction with $\mathrm{Cdc} 2$ following ionizing irradiation. Since $\mathrm{Cdk}$ inhibitor $\mathrm{p} 21^{\mathrm{CIP} 1 / \mathrm{WAF} 1}$ is also known to negatively regulate $\mathrm{G} 2 / \mathrm{M}$ transition as well as $\mathrm{G} 1 / \mathrm{S}$ transition, we investigated the possible role of $\mathrm{p} 21^{\mathrm{CIP} 1 / \mathrm{WAF} 1}$ in $\mathrm{G} 2$ arrest. As shown in Fig. 5A, p21 $1^{\mathrm{CIP} 1 / \mathrm{WAF} 1}$ was markedly induced both in the cytoplasmic and nuclear fractions after 4 Gy-irradiation: in the nucleus, p21 $1^{\mathrm{CIP} 1 / \mathrm{WAF} 1}$ was gradually accumulated until $12 \mathrm{~h}$ after irradiation, at which time the cells were arrested at G2. When the cells resumed cell cycle progression from G2 arrest, $\mathrm{p} 21^{\mathrm{CIP} 1 / \mathrm{WAF} 1}$ in the nucleus was decreased. Then, we examined the interaction between $\mathrm{p} 21^{\mathrm{CIP} 1 / \mathrm{WAF} 1}$ and $\mathrm{Cdc} 2$ in the nucleus. When the cells were arrested in G2 at $12 \mathrm{~h}$ of postirradiation, the interaction between $\mathrm{p} 21^{\mathrm{CIP} 1 / \mathrm{WAF} 1}$ and Cdc 2 was markedly increased concomitantly with inhibition of $\mathrm{Cdc} 2$ kinase activity in the nucleus (Fig. 5B), and the interaction gradually decreased after the cells were released from $\mathrm{G} 2$ arrest. Indirect immunofluorescence staining of p21 CIP1/WAF1 clearly showed periodical localization of $\mathrm{p} 21^{\mathrm{CIP} 1 / \mathrm{WAF} 1}$ to the nucleus following ionizing radiation (Fig. 5C). These data suggest that transient nuclear accumulation of $\mathrm{p} 21^{\mathrm{CIP} 1 / \mathrm{WAF} 1}$ and subsequent binding to $\mathrm{Cdc} 2$ may be critical in the inhibition of nuclear $\mathrm{Cdc} 2$ kinase activity during $\gamma$-irradiation-induced G2 arrest.

\section{Discussion}

In this study, we showed that the suppression of nuclear import of cyclin B1 and its associated kinase activity, the induction of Wee1 kinase activity and the transient nuclear accumulation of $\mathrm{p} 21^{\mathrm{CIP} 1 / \mathrm{WAF} 1}$ may play important roles in the ionizing radiation-induced transient $\mathrm{G} 2$ arrest.

Transition from $\mathrm{G} 2$ to $\mathrm{M}$ phase requires $\mathrm{Cdc} 2$ activity, which is in turn regulated by levels of cyclin B1 proteins as well as by phosphorylation status of $\mathrm{Cdc} 2$. In mammalian cells, phosphorylation of Cdc2 catalyzed by Wee1/Myt1 tyrosine kinases at Tyr15 and Thr14 is important in negative regulation of kinase activity, whereas dephosphorylation at the same sites is facilitated by $\mathrm{Cdc} 25$ tyrosine phosphatases $(18,19)$. Our data showed that exposure of the cells to $\gamma$-radiation led to a marked increase of cells in G2 at $12 \mathrm{~h}$ $(>80 \%)$. The levels of inhibitory phosphorylation of the Cdc2 on Y15 and Cdc25C on Ser216 were increased at $12 \mathrm{~h}$ after radiation, concomitant with G2 arrest. These results correlated well with a previous study demonstrating inhibitory phosphorylation of $\mathrm{Cdc} 2$ and $\mathrm{Cdc} 25 \mathrm{C}$ delay mitosis after DNA damage $(21,24)$. In addition, the level of phosphorylated Wee 1 and its activity were also markedly increased. It has been previously reported that DNA damage leads to tyrosine phosphorylation of Cdc2 (24). DNA damage up-regulates Wee1 kinase activity, a kinase that leads to Cdc2 inactivation by tyrosine phosphorylation. However, other studies have found that radiation does not have an effect on Wee1 kinase (9), suggesting that the regulation of
Wee1 kinase activity may be cell type-specific or that other inhibitory kinases may exist.

We observed that despite cyclin B1 induction and a marked increase of cyclin B1-associated kinase activity, cells remain partially arrested in $\mathrm{G} 2$. We found that when cells are arrested in G2 after irradiation, the cyclin B1 and cyclin B1associated kinase activity is localized in the cytoplasm for a substantial period of time. Earlier reports demonstrated that cyclin B1 expression was transiently reduced by DNA damage under certain conditions (10), that nuclear localization of cyclin B1 might regulate mitotic entry after DNA damage (21), and that DNA damage-induced G2 arrest was associated with nuclear export of cyclin B1 (26). In this study, we found that cyclin B1 was accumulated in the cytoplasm by inhibition of nuclear translocation after ionizing irradiation. We first observed a marked increase of cyclin B1 in the whole cell lysates at $12 \mathrm{~h}$ after radiation, although the cells were arrested in G2 phase. When examined more closely, there was no detectable change of cyclin B1 in the nucleus in spite of a marked increase of the same protein in the cytoplasm. Therefore, the question arose as to why cyclin B1 was induced and accumulated in the cytoplasm during the G2 arrest. One likely explanation is that radiation induces transient cell cycle arrest for DNA repair and the cells should then resume cell cycle progression as soon as the DNA repair is completed. To resume cell cycle progression, high level of cyclin B1 is required for the activation of Cdc2 in the nucleus. At this time point from 12 to $24 \mathrm{~h}$ after irradiation, the G2arrested cells may completely repair damaged nuclear translocation machinery, which then allows nuclear translocation of cyclin B1. When the cells resume cell cycle progression at $24 \mathrm{~h}$ or later, a marked translocation of cyclin B1 from the cytoplasm to the nucleus and concomitant increase of cyclin B1/Cdc2 kinase activity were observed in our present study.

Several observations suggest that cyclin-dependent kinase inhibitor (CKI) p21 plays an important role in G2/M checkpoint control. p21 $1^{\mathrm{CIP} 1 / \mathrm{WAF} 1}$ inhibits either kinase activity of $\mathrm{Cdc} 2$ or prevent its activation by directly binding to $\mathrm{Cdc} 2$, thereby blocking the interaction of cyclin B1-Cdc2 complexes with their substrates (27-29). In the present study, we observed that $\mathrm{p} 21^{\mathrm{CIP} 1 / \mathrm{WAF} 1}$ was markedly induced following ionizing irradiation and translocated into the nucleus at $12 \mathrm{~h}$. At the same time, there was a marked increase of Cdc2-p21 CIP1/WAF1 binding, and the increase of Cdc2-p $21^{\mathrm{CIP} 1 / \mathrm{WAF} 1}$ binding coincided with the inhibition of nuclear $\mathrm{Cdc} 2$ activity and transient G2 arrest. Later, when the cells resumed cell cycle progression from the $\mathrm{G} 2$ arrest, the level of nuclear $\mathrm{p} 21^{\mathrm{CIP} 1 / \mathrm{WAF} 1}$ and Cdc2-p21 ${ }^{\mathrm{CIP} 1 / \mathrm{WAF} 1}$ interaction decreased, thus facilitating cell cycle progression. Therefore, transient nuclear accumulation of $\mathrm{p} 21^{\mathrm{CIP} 1 / \mathrm{WAF} 1}$ might play a role in the radiation-induced G2 arrest. However, our results did not clearly discern whether the decrease of nuclear p21 $1^{\mathrm{CIP} 1 / \mathrm{WAF} 1}$ level was due to cytoplasmic export or degradation, when the cells resumed cell cycle progression. Further studies are needed to clarify the exact mechanism involved in the periodic nuclear localization of $\mathrm{p} 21^{\mathrm{CIP} 1 / \mathrm{WAF} 1}$.

In conclusion, we demonstrated that nuclear $\mathrm{Cdc} 2$ activity was regulated by complex mechanisms during the radiationinduced G2 arrest in the exponentially growing L929 cells. 
We showed that the inhibition of nuclear import of cyclin B1 and periodic nuclear localization of $\mathrm{p} 21^{\mathrm{CIP} 1 / \mathrm{WAF} 1}$ as well as inactivation of $\mathrm{Cdc} 25 \mathrm{C}$ and induction of Wee1 activity play roles in the suppression of nuclear $\mathrm{Cdc} 2$ activity during the arrest. These results may provide additional information to understand the precise mechanism of cell cycle regulation in normal cells, following ionizing radiation-induced genotoxic damage.

\section{Acknowledgements}

This work was supported by Korea Science and Engineering Foundation (KOSEF) and Ministry of Science and Technology (MOST), Korean government, through its National Nuclear Technology Program.

\section{References}

1. Smeets MF, Mooren EH and Begg AC: The effect of radiation on $\mathrm{G} 2$ blocks, cyclinB expression and $\mathrm{Cdc} 2$ expression in human squamous carcinoma cell lines with different radiosensitivities. Radiother Oncol 33: 217-227, 1994.

2. Szumiel I: Monitoring and signaling of radiation-induced damage in mammalian cells. Radiat Res 150 (Suppl): S92-S101, 1998.

3. Maity A, McKenna WG and Muschel RJ: Eviden ce for posttranscriptional regulation of cyclin $\mathrm{B} 1 \mathrm{mRNA}$ in the cell cycle and following irradiation in HeLa cells. EMBO J 14: 604-609, 1995.

4. Paulovich AG, Toczyski DP and Hartwell LH: When checkpoints fail. Cell 88: 315 321, 1997 .

5. Ning S and Knox SJ: G2/M-phase arrest and death by apoptosis of HL60 cells irradiated with exponentially decreasing lowdose-rate gamma radiation. Radiat Res 151: 659-669, 1999.

6. Baber-Furnari BA, Rhind N, Boddy MN, Shanahan P, Lopez-Girona A and Russell P: Regulation of mototic inhibitor Mik 1 helps to enforce the DNA damage checkpoint. Mol Biol Cell 1: 1-11, 2000.

7. Bunz F, Dutriaux A, Lengauer C, Waldman T, Zhou S, Brown JP, Sedivy JM, Kinzler KW and Vogelstein B: Requirements for P53 and P21 to sustain G2 arrest after DNA damage. Science 282: 1497-1500, 1998

8. Haimovitz-Friedman A: Radiation-induced signal transduction and stress response. Radiat Res 150 (Suppl): S102-S108, 1998.

9. Raleigh JM and O'Connell MJ: The G2 DNA damage checkpoint targets both Wee1 and Cdc25. J Cell Sci 113: 17271736,2000

10. Maity A, Mckenna WG and Muschel RJ: The molecular basis for cell cycle delays following ionizing radiation. Radiother Oncol 31: 1-13, 1994.

11. Yu L, Orlandi L, Wang P, Orr MS, Senderowicz AM, Sausville EA, Silvestrini R, Watanabe N, Piwnica-Worms H and O'Connor PM: UCN-01 Abrogates G2 arrest through a Cdc2-dependent pathway that is associated with inactivation of the Wee $1 \mathrm{Hu}$ kinase and activation of the $\mathrm{Cdc} 25 \mathrm{C}$ phosphatase. J Biol Chem 273: 33455-33464, 1998.

12. Badie C, Itzhaki JE, Sullivan MJ, Carpenter AJ and Porter AC: Repression of CDK1 and other genes with CDE and CHR promoter elements during DNA damage-induced G2/M arrest in human cells. Mol Cell Biol 20: 2358-2366, 2000.
13. Morgan DO: Principles of CDK regulation. Nature 374: 131-134, 1995.

14. Hwang A and Muschel RJ: Radiation and the G2 phase of the cell cycle. Radiat Res 150 (Suppl): S52-S59, 1998.

15. Zhan Q, Antinore MJ, WangXW, Carrier F, Smith ML, Harris CC and Fornace AJ Jr: Association with $\mathrm{Cdc} 2$ and inhibition of Cdc2/cyclinB1 kinase activity by the P53-regulated protein Gadd45. Oncogene 18: 2892-2900, 1999.

16. Park JS, Carter S, Reardon DB, Schmidt-Ullrich R, Dent P and Fisher PB: Roles for basal and stimulated P21cip1/WAF1/ MDA6 expression and mitogen-activated protein kinase signaling in radiation-induced cell cycle checkpoint control in carcinoma cells. Mol Biol Cell 10: 4231-4246, 1999.

17. Schmidt-Ullrich RK, Dent P, Grant S, Mikkelsen RB and Valerie K: Signal-transduction and cellular radiation responses. Radiat Res 153: 245-257, 2000.

18. Heald R, McLoughlin M and Mckeon F: Human Wee1 maintains mitotic timing by protecting the nucleus from cytoplasmically activated Cdc2 kinase. Cell 74: 463-474, 1993.

19. Peng CY, Graves PR, Thoma RS, Wu Z, Shaw AS and Piwnica-Worms H: Regulation of 14-3-3 protein binding by phosphorylation of Cdc25C on serine-216. Science 277 : 1501-1504, 1997

20. Dulic V, Stein GH, Far DF and Reed SI: Nuclear accumulation of p21cip 1 at the onset of mitosis: a role at the G2/M-phase transition. Mol Cell Biol 18: 546-557, 1998

21. Jin P, Hardy S and Morgan DO: Nuclear localization of cyclinB1 controls mitotic entry after DNA damage. J Cell Biol 141: 875-885, 1998

22. Kim JY, Choi JA, Kim TH, Yoo YD, Kim JI, Lee YJ, Yoo SY, Cho CK, Lee YS, Lee SJ: Involvement of p38 mitogenactivated protein kinase in the cell growth inhibition by sodium arsenite. J Cell Physiol 190: 29-37, 2002.

23. Schnier JB, Nishi K, Goodrich DW and Bradbury EM: G1 arrest and down-regulation of cyclin E/cyclin-dependent kinase 2 by the protein kinase inhibitor staurosporine are dependent on the retinoblastoma protein in the bladder carcinoma cell line 5637. Proc Natl Acad Sci USA 93: 5941-5946, 1996.

24. Jin P, Gu Y and Morgan DO: Role of inhibitory CDC2 phosphorylation in radiation-induced G2 arrest in human cells. J Cell Biol 134: 963-970, 1996

25. Tuel-Ahlgren L, Jun X, Waddick KG, Jin J, Bolen J and Ucken FM: Role of tyrosine phosphorylation in radiationinduced cell cycle-arrest of leukemic B-cell precursors at the G2-M transition checkpoint. Leuk Lymphoma 20: 417-426, 1996.

26. Toyoshima F, Moriguchi T, Wada A, Fukuda M and Nishida E: Nuclear export of cyclin B1 and its possible role in the DNA damage-induced G2 checkpoint. EMBO J 17: 2728-2735, 1998.

27. Vikhanskaya F, Erba E, D'Incalci M and Broggini M: Changes in cyclins and cyclin-dependent kinases induced by DNA damaging agents in a human ovarian cancer cell line expressing mutated or wild-type p53. Exp Cell Res 227: 380-385, 1996.

28. Arita Y, Buffolino P and Coppock DL: Regulation of the cell cycle at the G2/M boundary in metastatic melanoma cells by 12-O-tetradecanoyl phorbol-13-acetate (TPA) by blocking p34cdc2 kinase activity. Exp Cell Res 242: 381-390, 1998.

29. Smits VA, Klompmaker R, Vallenius T, Rijksen YG, Makela TP and Medema RH: p21 inhibits thr161 phosphorylation of cdc2 to enforce the G2 DNA damage checkpoint. J Biol Chem 275: 30638-30643, 2000. 